\title{
STUDIES ON FOLIICOLOUS FUNGI - V TWO NEW SPECIES AND VALIDATION OFA SARCINELla SPECIES
}

\author{
V.B. Hosagoudar
}

Microbiology Division, Tropical Botanic Garden and Research Institute, Palode, Thiruvananthapuram, Kerala 695562, India.

\begin{abstract}
This paper gives an account on foliicolous fungi collec ted from the Western Ghats of peninsular India. Of these, Asterina gomphandrae and Sarcinella hugoniae are new species while Sarcinella gymnosporiae is validated. Phyllactina gmelinae Hosag. et al has priority.
\end{abstract}

\section{Keywords}

Asterina, Sarcinella, new species

\author{
Abbreviations \\ HCIO - Herbarium Cryptogamae Indiae Orientalis, New Delhi \\ TBGT - Tropical Botanic Garden, Thiruvananthapuram
}

\section{Asterina gomphandrae V.B. Hosagoudar et C.K. Biju, sp. nov.} (Fig. 1)

\section{Materials examined}

Holotype: 6.i.1999, Mannavan Shola, Idukki, Kerala, India, on leaves of Gomphandra sp. (Icacinaceae), coll. C.K. Biju, HCIO. Isotype: 6.i.1999, Mannavan Shola, Idukki, Kerala, India, on leaves of Gomphandra sp. (Icacinaceae), coll. C.K. Biju, TBGT.

\section{Distribution}

India: Mannavan Shola, Idukki in Kerala

\section{Diagnostic features}

Coloniae amphigenae, plerumque epiphyllae, subdensae vel densae, ad Imm dia., confluentes. Hyphae rectae vel flexuosae, irregulariter acuteque ramosae, laxe vel dense reticulatae,

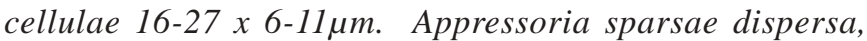
unicellula, antrorsa vel subantrorsa, ovata, oblonga vel cylindracea, integra, 16-20 $\times$ 9-11 $\mu \mathrm{m}$. Thyriothecia dispersa vel connata, orbicularia, ad 140 4 m dia., crenata vel fimbriata ad margine, hyphae fringiorae flexuosae vel anfractuae et non appressoriatae, thyriothecia stellatim dehiscentes ad centro; asci globosi, octospori, ad 50 $\mu$ m dia.; ascosporae oblongae,

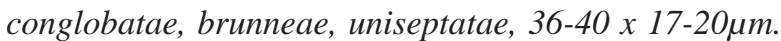

Colonies amphigenous, mostly epiphyllous, subdense to dense, up to $1 \mathrm{~mm}$ in diameter, confluent. Hyphae straight to flexuous, branching irregular at acute angles, loosely to closely reticulate, cells 16-27 x 6-11 $\mu \mathrm{m}$. Appressoria more scattered, unicellular, antrorse to subantrorse, ovate, oblong to cylindrical, entire, 16$27 \times 9-11 \mu \mathrm{m}$. Thyriothecia scattered to connate, orbicular, up to $140 \mu \mathrm{m}$ in diameter, margin crenate to fimbriate, fringed hyphae flexuous to crooked and non appressoriate, thyriothecia stellately dehisced at the centre; asci globose, octosporous, up to $50 \mu \mathrm{m}$ in diameter; ascospores oblong, conglobate, brown, uniseptate, $36-40 \times 17-20 \mu \mathrm{m}$.

\section{Remarks}

Asterina mappiae Petrak and Ciferri, and Asterina natsiati Kar and Maity are known on the members of the family Icacinaceae (Petrak \& Ciferri, 1930; Kar \& Maity, 1970; Hosagoudar \& Abraham, 2000). However, Asterina gomphandrae differs from both in having unicellular, oblong to cylindrical and entire appressoria, and having larger ascospores. 


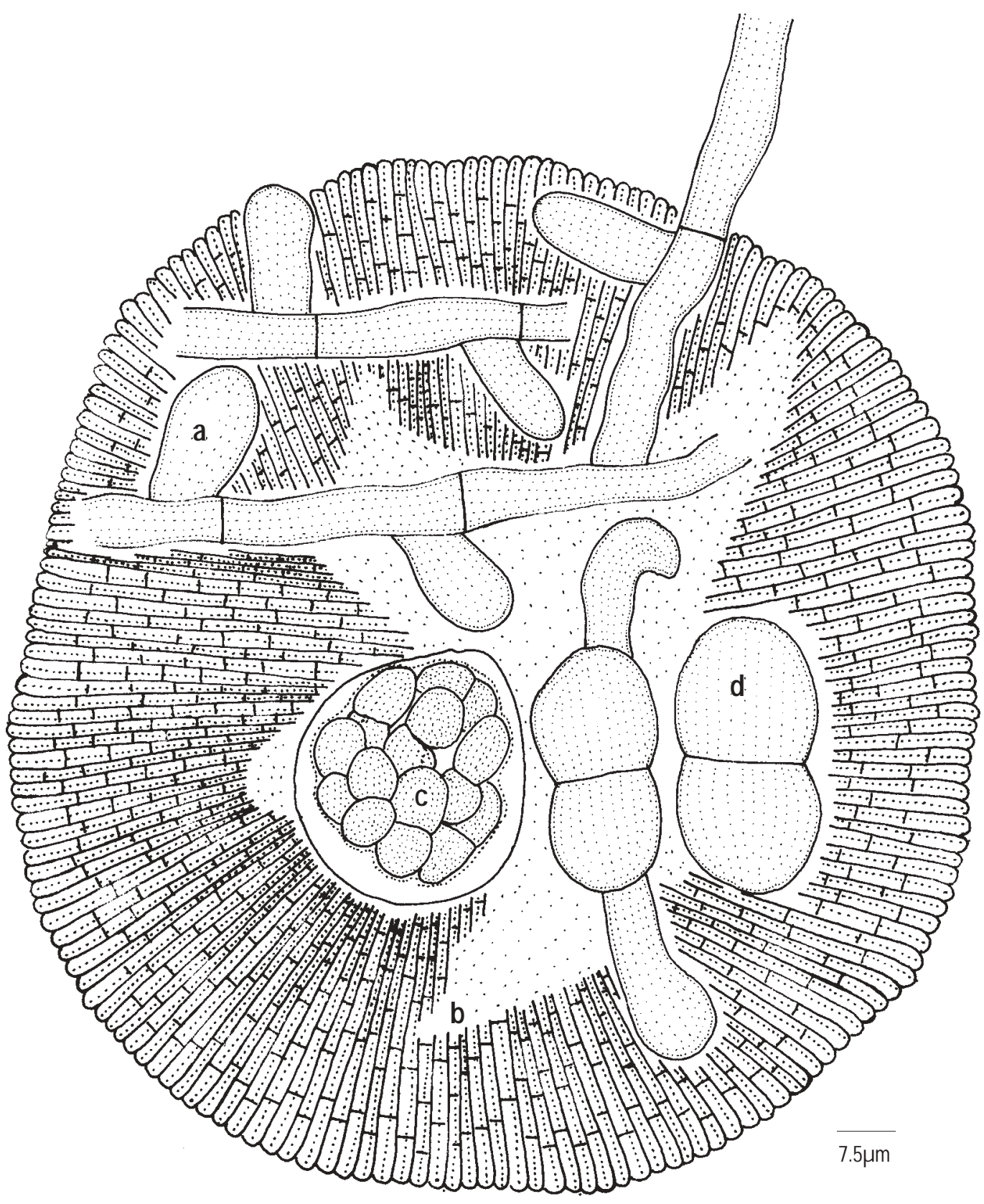

Figure 1. Asterina gomphandrae sp. nov.

a - Appressoriate mycelium; $b$ - Ascus; $c$ - Ascospores; $d$ - Sarciniform conidia 


\section{Phyllactina gmelinae Hosagouder, Boppammal \& Udaiyan}

Indian J. Trop.Biod. 1:318, 1993.

= Phyllactina suffulta (Rabent.) Sacc. var. gmelinae Patil, Curr. Sci. 30: 156,1961

= Phyllactina gmelinae Braun \& Bagyanarayana, Sydowia 51: $1,1999$.

\section{Material examined}

20.xii.1959, Chikhalda, Maharashtra, India, on leaves of Gmelina arborea (Verbenaceae), coll. B.V. Patil.

\section{Distribution}

India: Chikhalda in Maharashtra.

\section{Sarcinella gymnosporiae Subhedar \& Rao ex V.B. Hosagoudar, sp. nov.}

Sarcinella gymnosporiae Subhedar \& Rao, Biovigyanam 1: 194, 1975 (nom. nud.)

\section{Materials examined}

Holotype: 7.xi.1973, Simhagad, Pune, Maharashtra, India, on leaves of Gymnosporia rothiana (Celastraceae), coll. A.W. Subhedar AMH 2741.

\section{Distribution}

India: Simhagad, Pune in Maharashtra

\section{Diagnostic features}

Coloniae amphigenae, plerumque epiphyllae, subdensae, ad $1 \mathrm{~mm}$ dia., confluentes. Hyphaeflexuosae, irregulariter acuteque vel laxe ramosae, laxe vel fortiter reticulatae, celluale 12-20x 3-5 $\mu$ m. Appresoria plerumque opposita, raro tri-numero

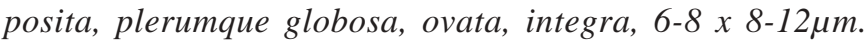
Conidia Questieriella pauca, gerrninatio, falcata, pallid

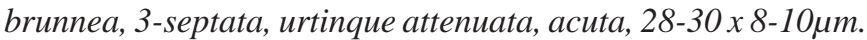
Conidia Sarcinellae numerosa; conidiophora macronemata, unicellula vel unisepstata, simplices pallid brunnea; cellulae conidiogenae monoblasticae integratae, teminaliae, determinatae; conidia solitaria, subspherica, sarciniformes, 4-8 cellula, nigra-brunnea, constricta, 17-24 x 14-28um, parietus glabrus.

Colonies amphigenous, mostly epiphyllous, subdense, up to $1 \mathrm{~mm}$ in diameter, confluent. Hyphae flexuous, branching irregular at acute to wide angles, loosely to closely reticulate and form a loose net of mycelia, cells 12-20 x 3-5 $\mu \mathrm{m}$. Appressoria mostly globose, often ovate, entire, 6-8 x 8-12 $\mu \mathrm{m}$. Questeriella conidia very few, germinating, falcate, pale brown, 3 -septate, tapering towards both ends, acute, $28-30 \times 8-10 \mu \mathrm{m}$. Sarcenella conidia many; conidiophores macronematous, entire to 1-septate, simple, pale brown; conidiogenous cells monoblastic, integrated, terminal, determinate; conidia solitary, subspherical, sarciniform, 4-8 celled, dark-brown, constricted at the septa, $17-24$ x 14-28 $\mu$ m, wall smooth.

\section{Sarcinella hugoniae V.B. Hosagoudar et M. Kamarudeen, sp. nov.}

(Fig. 2)

\section{Materials examined}

Holotype: 3.xii.2000, Malapuram, Kerala, India, on leaves of Hugonia mystax L. (Linaceae), coll. M. Kamarudeen, HCIO. Isotype: 3.xii.2000, Malapuram, Kerala, India, on leaves of Hugonia mystax L. (Linaceae), coll. M. Kamarudeen, TBGT.

\section{Distribution}

India: Malapuram in Kerala

\section{Diagnostic features}

Coloniae epiphyllae, densae, ad 3mm diam., confluentes. Hyphae subrectae vel flexuosae, irregulariter acuteque ramosae, laxe vel fortiter, reticulatae, cellulae 16-23 x 7-9 $\mu \mathrm{m}$. Questieriella conidia nulla. Sarcinella conidia visa; conidiophora maconemata, unicellula vel raro uniseptata,

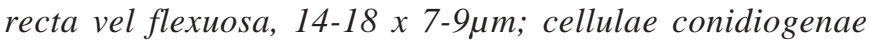
monoblasticae, integratae, terminaliae, determinatae; conidia solitaria, subspherica et ovata, sarciniformes, nigra, 4-6 cellula, constricta, 32-40 × 28-32 $\mu \mathrm{m}$, parietus glabrus.

Colonies epiphyllous, dense, up to $3 \mathrm{~mm}$ in diameter, often confluent. Hyphae substraight to flexuous, branching irregular at acute angles, loosely to closely reticulate and form solid mycelial mat, cells 16-23 x 7-9 $\mu \mathrm{m}$. Questieriella conidia absent. Sarcenella conidia present; conidiophores macronematous, unicellular to rarely uniseptate, straight to flexuous, 14-18 x 7$9 \mu \mathrm{m}$; conidiogenous cells monoblastic, integrated, terminal, determinate; conidia solitary, subspherical to ovate, sarciniform, black, 4-6 celled, constricted at the septa, 32-40 x 28-32 $\mu$ m, wall smooth.

\section{Remarks}

This forms the first report of the genus Sarcinella on the members of the family Linaceae (Hughes, 1987). This collection was severely parasitized with Acremoniula sarcinellae (Pat. \& Har.) Arn. ex Deight.

\section{Acknowledgements.}

The author thanks Dr. G. Sreekandan Nair, Director and Dr. T.K. Abraham, Deputy Director, TBGRI for encouragement and Drs. K. Ravikumar, FRLHT and R. Ganesan, ATREE, Bangalore for identification of host plant. Prof. P.F. Korf is acknowledged here for suggestions on nomenclature. 


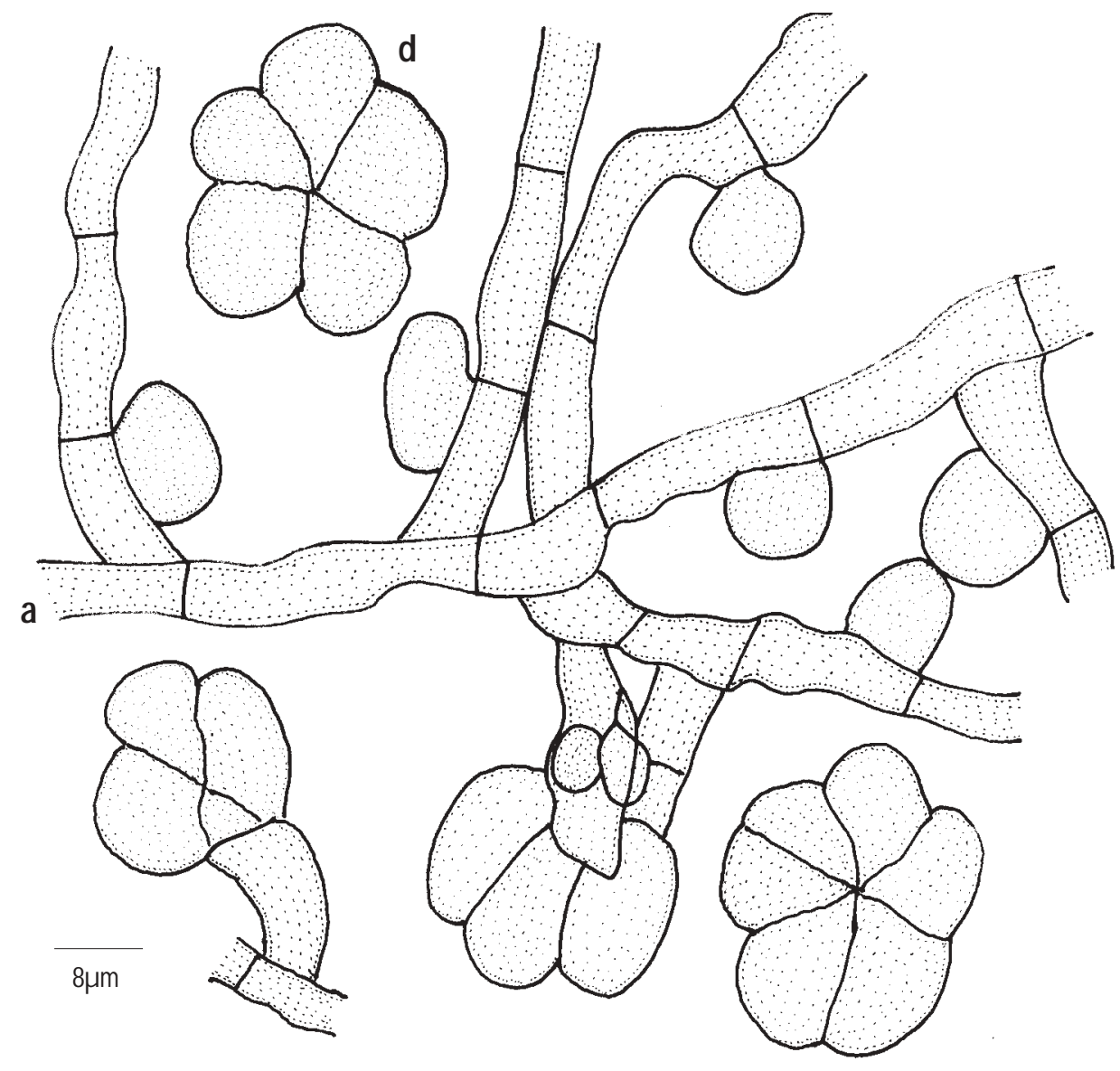

Figure 2. Sarcinella hugoniae sp. nov. a - Appressoriate mycelium; $d$-Sarciniform conidia

\section{References}

Hosagoudar, V.B. and T.K. Abraham (2000). A list of Asterina Lev. species based on the literature. Journal of Economic and Taxonomic Botany 24: 557-587.

Hughes, S.J. (1987). Plemorphy in some hyphopodiate fungi, pp. 103-139. In: Sugiyama (Editor) Pleomorphic fungi. The Diversity and its Taxonomic Implications. Kadansha \& Elsevier, Tokyo \& Amsterdam. Kar, A.K. and M.K. Maity (1970). New Asterina spp. from West Bengal. Transcripts of the British Mycology Society 54: 435-444.

Petrak, F. and R. Ciferri (1930). Fungi Dominicani. Annals of Mycology 28: $377-420$. 